\title{
Music and well-being
}

\author{
JBOYCE-TILLMAN
}

\begin{abstract}
This paper scrutinizes how human beings relate to the wider cosmos in the thinking of the European Middle Ages. The re-invention of the 'spiritual' might liberate Western culture from Cartesian elements within Western Christianity and the consequent limited and exclusive views of musicking. Practical examples of how singing together forms community at a variety of levels will be discussed. Others aspects that will be addressed are: being human; culture, health and illness; the place of the spiritual and the implications of this for music education.
\end{abstract}

Keywords. Music education, singing, community, well-being, spirituality, musicking

\section{Introduction}

This paper (originally given as a keynote presentation) ${ }^{2}$ will explore the view of what it is to be human and how well-being is constructed (Helman, 1994). In this context it will scrutinize how human beings relate to the wider cosmos in the thinking of the European Middle Ages. I shall further explore how process models of well-being (Whitehead, 1929; Dewey, 1934 \& Shusterman, 2008) can inform the place of music as a source of well-being (Small, 1998). This paper shall also discuss how the re-invention of the 'spiritual' (Heelas \& Woodhead, 2005; Wigglesworth, 2005) might liberate Western culture from Cartesian elements within Western Christianity (Claxton, 2010) and how this resulted in limited and exclusive views of musicking. I shall also argue the re-invention of the idea of the 'spiritual' challenges, the sacred/secular divide (Bender, 2010) and the potential for enabling a musical pedagogy based on respectful encounter (Levinas, 1969; Buber, 1970; Ellis, 1985; Tisdell, 2007, Boyce-Tillman, 2010; Nussbaum, 2012).

Thus, the emerging methodology for the current study is crystallization. This methodology is a qualitative approach seeking to gain insight into a particular phenomenon through an indepth understanding of its complexity (Richardson, 2000b):

In postmodernist mixed-genre texts, we do not triangulate, we crystallize ... I propose that the central image for "validity" for postmodern texts is not the triangle - a rigid, fixed, two-dimensional object. Rather, the central imaginary is the crystal, which

1. Rev Dr June Boyce-Tillman is a professor of Applied Music at Winchester University in the UK, and an Extraordinary Professor at North-West University, Potchefstroom campus (niche entity - Musical Arts in South Africa: Resources and Applications). She is a popular international keynote speaker and was appointed Member of the Order of the British Empire (MBE) for her contribution to music and education. June.Boyce-Tillman@ $@_{\text {winchester.ac.uk }}$

2. There were performative elements in the original presentation, which are difficult to encapsulate in an academic paper. I have endeavoured to summarise the gist of them in written form in this article. It is in line with the crystallization methodology. 
combines symmetry and substance with an infinite variety of shapes, substances, transmutations, multidimensionalities, and angles of approach (Richardson 2000:934, original emphasis).

This allows for a variety of writing styles (and in the actual keynote presentation performative elements) to explore music and well-being by means of an interdisciplinary weaving together of philosophy, theology, music (as approached by musicology, ethnomusicology, music therapy), hymns, poetry and musical practice. Crystallization sees truth as a crystal with different facets revealing different aspects of truth:

Crystallization combines multiple forms of analysis and multiple genres of representation into a coherent text or series of related texts, (Ellingson, 2009:4).

\section{Singing and Community}

The first performative event was designed to demonstrate how singing together forms community at a variety of levels. Recent research in neuroscience at the University of Gothenburg has confirmed this and linked it with emotional well-being:

Singing in a choir is as good as yoga because the breathing patterns can regulate your heart beat. When choir members sing together their heartbeats become synchronised growing faster and slower at the same time as they breathe in and out in unison, the researchers found. The study could explain why choral singing is said to be good for your health, because reducing the variability of your heart rate is likely to be good for your well-being, they said. It also suggests singing can enhance the spirit of co-operation in a group because it helps regulate activity in the brain's vagus nerve, which is linked to emotion and communication with others. The researchers, from the University of Gothenburg, studied the heart rates of 15-18 year old choral singers as they performed three different vocal exercises: humming, singing a Swedish hymn and chanting a slow mantra. The combined results showed that the melody and the structure of the music directly affected singers' heart rates and that singing in unison caused their pulses to rise and fall at the same time (Collins, 2013:5).

It is on the basis of such claims that I asked the group present to take their pulse and listen to the different speeds of the heartbeats within our group. Then we sang together:

\section{CHORUS}

Sing us our own song the song of the earth, The song of creation, the song of our birth, That exists in belonging to you and to me, To the stars and the mountains, the sky and the sea.

1. Listen! You're hearing the song of the earth, They sing it who know of their value and worth, For they know they belong with the sea and the sky, To the moonshine at midnight, the clouds floating by.

\section{CHORUS}

2. It is not one song but patchworks of sound.

That includes all the pitches that people have found

That includes the vibrations of earthquakes and bees 
CHORUS

Of the laughing fire's crackling and murmuring breeze.

3. All blend together to make the earth song,

Fragmented parts separated too long,

True notes and rhythms and colours and beat

Make sacred spaces where we all meet.

CHORUS

(Boyce-Tillman, 2006b).

Following the singing I asked everyone to take their pulse again and we found that all our pulses had entrained with one another. We had become more like one another physically by communal musicking. In Music and Mind, Anthony Storr (1993) sees this as the main purpose of musicking - to create community. The song also implies that this is a community that extends beyond the human community. Storr's notion of a cosmic community would possibly have been the prevailing philosophy/theology of mediaeval Europe in the work of people like Hildegard of Bingen (Boyce-Tillman, 2000c).

\section{Being Human}

Where does the notion of community sit in Western thinking about what it is to be human today? Many would say that one of the most serious losses in the globalisation of capitalism is a sense of community. Central to this may be the loss of communal contexts for singing like church or synagogue services. The dominant model of the self is now one of an often aggressive individualism (Boyce-Tillman, 2007b).

As I was driven to the Potchefstroom campus I passed a number of villages - houses huddled together with a real sense of a close community or ubuntu. Many in the West are drawing on this traditional concept:

One of the sayings in our country is Ubuntu - the essence of being buman. Ubuntu speaks particularly about the fact that you can't exist as a buman being in isolation. It speaks about our interconnectedness. You can't be human all by yourself, and when you have this quality - Ubuntu - you are known for your generosity (Tutu, 2008).

But the great march of global capitalism is on the way to obliterating such ideas which make community central to what it is to be human; for such ideas do not fit with its aim of controlling notions of humanity to serve its own needs. Thinkers like Cathy Benedict see how within global capitalism ideas of competition between humans have become institutionalised:

The point ... is that competition at global level has indeed become institutionalised ... A class system that provides the mechanisms for the satisfaction of profit and a division of labor that produces "a product whose goal is not to satisfy human needs but rather to re-order the lives of the people who come into contact with it" (Ollman, 1976:200 in Benedict, 2013:15-16).

Such a way of ordering society is creating a community to serve the ends of those at the top the rich - rather than one based on mutual service and understanding. In particular, it is not one that values diversity. A capitalist economy ... creates and enacts the "universal subject of 
the modern state" (Lyon, 1999:5). So, our society is structured to create community based on a class structure that requires "the invention of a new class of poor and a new definition of poverty" (Illich, 1972:4). Thus far, encouraging the development of a rich humanist education resulted in dedication towards serving capitalist ends rather than giving people the tools for creating a community of mutuality

One needs educated workers. And this ritualized progression of global competitiveness serves to create further divisions of labour and class and confusion between teaching and learning (or learning as "certification" and commodification) (Benedict, 2013:16-17).

I have been composing a piece portraying the ideas of the futures of capitalism entitled The Great Turning (Boyce-Tillman, 2014), in which darkness is portrayed by the repeated ostinato of "They are not serving us; we are serving them". My suggestion is that attending to the spiritual aspects of education could provide a chance of rehumanizing our educational systems.

\section{Culture, Health and Illness}

Our state institutions like education and medicine have become organized around the capitalist goals described above, which may be regarded as limiting what it truly means to be human. Cecil Helman (1994) in his book Culture, Health and Illness describes three models that underpin thinking about the health of the body which is inextricably bound up with what it means to be human. These models are:

The balance/imbalance model - "the healthy working of the body is thought to depend on the harmonious balance between two or more elements of forces within the body" (Helman, 1994:21).

The plumbing model - "the body is conceived of as a series of hollow cavities or chambers, connected with one another, and with the body's orifices, by a series of "pipes" or "tubes" ... Central to this model is the belief that health is maintained by the uninterrupted flow of various substances ... between cavities, or between a cavity and the body's exterior via one of the orifices" (Helman, 1994:24-25).

The machine model - "the conceptualization of the body as an internal combustion engine, or as a battery-driven machine, has become more common in Western society" (Helman, 1994:26).

The first of these has far greater scope for the inclusion of mind and soul than either of the others. Medieval cosmic schemes tended to see the world as a whole as being constantly in a state of rebalancing and the notion of healing as balance/imbalance fitted better in such a view of the world. John Foskett (1984), dealing with mental health, identifies a variety of models which include:

- The medical model which sees mental disturbance as the result of a chemical deficiency;

- The psychodynamic model based on the work of analysts like Freud;

- The behavioural model which deals in cause and effect and is influenced by experimental psychology and learning theory;

- The social model that emphasises the effect of social deprivation (Foskett,1984).

The above mentioned models show a variety of locations for the disturbance leading us to see how complex our humanity is. Although the most useful model for music as well-being is 
balance, we have already seen how current research is accommodating the emotional and I will integrate into this the spiritual. If we put together aspects of these models with current research we get a version of a human being who has the following domains within the self:

1. Material (or physical) - i.e. has parts moving and so on but those parts are inextricable bound together through the natural world;

2. Emotional and feelingful - a domain that includes personal history, natural and behavioural circumstances, interpersonal and intrapersonal areas and notions of identity;

3. Mind - a domain associated with reason and thinking;

4. Social situatedness - which will be in a variety of contexts involving a variety identities;

5. Spiritual- which includes some sense of the beyond.

\section{The Place of the Spiritual}

I wrote this poem after conducting a performance of one of my own pieces. For me, it was a real glimpse of glory and as with many of these experiences it was not planned but was rather connected to the musicking experience.

\section{It was as if}

I went to the garden as the sun was descending ...

It was as if the great ferns had grown longer and greener

It was as if the greening power of the earth was everywhere - filling

the world with love and strength

It was as if the entire world was singing

It was as if I love everything and everything loved me

It was as if I had found the place I was really meant to be

It was as if I was in the place just right - the valley of love and delight

It was as if God had made me just for this moment

It was as if I was alive for the first time

It was as if I saw the world made new

It was as if the garden enclosed me and held me safe

It was as if everything was higher than it had ever been

It was as if everything was cool

It was as if nothing mattered but this one moment of Divine promise

(Boyce-Tillman, 2011).

Theorists are gradually bringing into their models an element of the spiritual in an effort to identify the limitations in the dominant machine models of what it means to be human. Rowson calls this unease spiritual embarrassment:

Spiritual embarrassment is grounded in confusion about buman nature and buman needs ... Surely religions are the particular cultural doctrinal and institutional expressions of human spiritual needs which are universal? ... Compare the designations 
"educated, but not due to schooling" or "bealthy but not because of medicine" (Rowson, 2013:42).

He goes on to identify some of the problems which our current systems are not tackling effectively as spiritual:

When you consider how we might, for instance, become less vulnerable to terrorism, care for an aging population, address the rise in obesity or face up to climate change, you see that we are - individually and collectively - deeply conflicted by competing commitments and struggling to align our actions with our values... The best way to characterise problems at that level is spiritual (Rowson, 2013:40).

In order to understand how we got to this opposition we need to examine how the present concept of the spiritual developed.

\section{A brief history of spirituality}

In the nineteenth century Nietzsche declared God dead and thus spirituality (Heelas \& Woodhead 2005) can be seen as a solution to the loss of God. Robert Fuller, in his book Spiritual but not Religious (2001), traces its roots into the nineteenth century, linking it with such movements in the US as Transcendentalism, Swedenborgianism, Theosophy, Spiritualism and Eastern Religions. The Transcendentalists centring on Ralph Waldo Emerson drew on Kant's view of the transcendental to see it as all the intuitive aspects of the mind. Swedenborgianism was a system of philosophical and religious doctrines which asserted the spiritual nature of the universe. The Theosophical Society in 1875 saw the oneness of all life. From this Rudolf Steiner developed anthroposophy which stresses the centrality of the quest for the spiritual/transcendent to what it is to be human.

During the $19^{\text {th }}$ century the notion of the perennial philosophy developed the idea of a universal truth underpinning the various religious traditions. Organized religions such as Christianity, Taoism, Buddhism, Sikhism, Hinduism, and Islam are seen to be derived from this universal truth (Huxley, 1945). Notions of spirituality therefore included other faith traditions, as in World Spirituality: An Encyclopaedic History of Religious Quest, (Dupre, 1990) which included twenty-five examples of 'spirituality spanning a range of eras and faith traditions'.

However, if underpinning all this is a search for an essential unity at the heart of religious thinking, in the early $21^{\text {st }}$ century diversity reasserts itself as King suggests:

It is ... much more appropriate to speak of 'spiritualities' rather than spirituality in the singular. Christian spirituality differs from Jewish, Muslim, Hindu or Buddhist spirituality ... Many contemporary spiritualities have come into existence which are not defined by traditional religions but are secular or newly created (King, 2009:4).

The current development of consciousness studies has entered this area of the interconnectedness of creation with figures like Ken Wilber (2009).

\section{Missing God}

This history of spirituality could be seen as varied attempts to fill the hole left by religion. Alain de Botton - a self-declared atheist - turns to the arts as a replacement for God. 
Following a similar line, the atheist philosopher Alain de Botton, warns that before we dismiss religion we must ask the reasons for its existence:

\begin{abstract}
[First] the need to live together in communities in harmony, despite our deeply rooted selfish and violent impulses. And second, the need to cope with terrifying degrees of pain which arise from our vulnerability to professional failure, to troubled relationships, to the death of loved ones and to our decay and demise... The error of modern atheism is how many aspects of the faiths remain relevant even after their central tenets have been dismissed... There might be a way to engage with religion without having to subscribe to its supernatural content (De Botton, 2012:5-6).
\end{abstract}

Thus, we are looking for processes that will comfort us and give us a sense of belonging, which can be related to the musical experience.

\title{
Process or product
}

We live in a product centred society which has little concern for the methods by which a particular product is produced. Success is often associated with a particular product - an exam result, a qualification, a transaction, a new job, a partnership. It is associated with commodification in our society. Human beings are invited to package themselves with branded names and life styles that make them a certain sort of product. Image makers are paid to support this process. Advertising offers a range of options in terms of image whether it is for dwelling place, domestic gadgetry, sports equipment, plastic surgery or a typology of children. Doing - i.e. producing products - has become dominant and being has consequently become a subjugated valueless way of knowing. Capitalism deals only in products. This value system validates de-humanizing forms of production and the rape of the earth for the materials of production. Schools and exams are also commodified. MacFarlane roots this tendency in education with the passing on of the literate religions:

The task of education was to instil truth in young minds through repetition. There was no questioning, just some explanation, elaboration, leaving out of obscure meanings. This tendency was reinforced as wealth increased. There were more priests and teachers; the ability to pass examinations on the texts became ever more important as the key to power and status; the period of education became ever longer... Mental worlds were, if anything, increasingly closed. Truth was asserted and given sanction by being written down ... there was nothing new to be said or thought (MacFarlane, 2005:141).

The workplace is increasingly literate and the orate ${ }^{3}$ can find no place in it, whereas processes, in general, contain a higher level of oracy:

Knowledge has been passed on through most of history by word of mouth. This does not allow much criticism. Nothing is written down, so different versions cannot easily be compared. There is no 'external truth' or 'way' providing an orthodoxy from which there can be deviations (MacFarlane, 2005:140).

3. The words "literacy" and "oracy" refer to processes of communication. The terms "literate" and "orate" refer to societies which use either the written word or the spoken word as the prime means of communication (Ong, 1982). 
This paper sees how theologians have challenged a product-based view of life to produce more process-based models of spirituality that roots it more in a series of interactions rather than belief in a codified and reified Divine being of some kind.

\section{The God Delusion}

The term "God delusion" comes from a text by Richard Dawkins (2006) in which he claims that a personal belief in a supernatural creator is a delusion. This leads him to a description of religion as a shared insanity. The sales of this book - which reached 2 million copies by January 2010 indicates the popularity of the ideas that he sets out. He is following in the footsteps of authors like Philip Pullman who similarly describes in The Amber Spyglass, a puny male divine figure that draws on Western iconography of some 1500 years including the popular creation one on the ceiling of the Sistine Chapel by Michelangelo. The narrative of Christianity developed this anthromorphic view of God only after 300 years of the use of symbols like the fish. They surrounded this idolatrous representation with creeds and dogmas to support it still reflected in the male hierarchical structures of many of the Christian traditions.

The move in our culture towards a personal descriptor of spiritual but not religious has, in general, rebelled against the systematisation of the supposed teachings of their founding figures (which are often passed down initially orally resulting in a problematic access to the figures themselves - like Jesus) creeds and dogmas outlined by McFarlane above and underpinning the atheism of the likes of Pullman and Dawkins. Characteristics of spiritual but religious can be summarised as:

- A rejection of creed and dogma and a source of truth;

- A valuing of experience over received tradition;

- An embracing of plurality in belief frames;

- A celebration of the mysterious and paradoxical linked with experiences of awe and wonder - the 'sacred ignorance' of the theology of liberation theologians (Keller \& Danielle, 2002; Christ, 2003);

- A notion of spirituality as potentially transformative encounter;

- An awareness of a wider connectivity in the universe;

- A sense of journeying or seeking which draws on process philosophy and theology (Whitehead, 1929) underpinning the aesthetics of Dewey (1934) and Shusterman (2008).

The problematic nature of the God delusion that I was instructed into as a child I expressed in a hymn, which reworks one that I regularly sang as a child:

Finding God (with apologies to Mrs Emily Huntington Miller)

1. A child once loved the story

Which angel voices tell

How once the King of Glory

Came down on earth to dwell.

2. Now, Father God, I miss you - 
Your beard, your robes, your crown -

But you have served us badly

And let us humans down.

3. So easy to disprove you

And doubt your truthfulness;

For you were just an idol

That kept Your power suppressed.

4. For You are deep within us -

Revealed within our deeds, Incarnate in our living

And not within our creeds.

5. No image cannot hold you;

And, if to one we hold, We keep some from your loving

And leave them in the cold.

6. Excluded groups are legion -

Disabled, female, gay -

Old Father of the heavens,

Your picture moves away.

7. Life's processes reveal You -

In prison, death and war,

In people who are different,

In gatherings of the poor.

8. For Godding means encounter,

Gives dignity to all,

Has every shape and no shape -

In temple, tree and wall.

9. So we will go a-godding

And birth You in our world;

In sacrificial loving

We find Your strength unfurled

(June Boyce-Tillman, 2012 unpublished).

My conclusion is that we have lived with a God delusion for a long time and that this was revealed to us by the prominent atheist writers of our day whose position would be impossible without this particular narrative of the Divine. If we change our view of the spiritual to view it as a process and not a product, the atheistic position would be much more difficult to defend. Such a society would be open to much wider possibilities for accessing ways of knowing beyond the rational and every day - a condition longed for by the human products of a post-Nietzschean God-is-dead pseudo-secularised society. 


\section{A Process-based spirituality - Going a-Godding}

The notion of a way of being as the essence of Christianity rather than a commitment to a certain set of facts set in a particular narrative have been a strand of Christian thought for some time. Christological scholars have been rethinking Jesus's development of the idea of the Kingdom in a more process-based light - not as a thing to be achieved but as an on-going co-operation between human beings and God (Crossan, 1992:29f). Feminist theologians have also drawn on the development of process thought (Daly, 1973; Grey, 1989). Ruth Mantin writes that she wishes to see spirituality as process and sacrality as performative (Mantin, 2002) seeing the process as never completed. Carol Christ (2003) saw change as at the heart of the Divine. I have attempted to capture these ideas in this song:

\section{CHORUS}

And we'll all go a-godding

To bring the world to birth.

1. New life is calling;

Help set it free.

And we'll all go a-godding

With a song of liberty.

CHORUS

CHORUS

2. Hunger is calling,

Find food to share;

And we'll all go a-godding

To give out abundant care.

CHORUS

CHORUS

\section{Hopelessness calling}

Lonely and drear;

And we'll all go a-godding

In warm friendship drawing near.

4. Warfare is calling.

When will it cease?

And we'll all go a-godding,

In our arms, the flowers of peace.

CHORUS

5. Justice is calling

Scales in her hand;

And we'll all go a-godding,

In her strength we'll take a stand.

CHORUS

6. Wisdom is calling;

Search out her ways;

And we'll all go a-godding,

To the ending of our days.

(June Boyce-Tillman, 2006b). 
Process spirituality finds its expression in breaking down the sacred secular divide as we encounter the Divine in unusual places:

... did we see that day the unseeable

one glory of the everlasting world

Perpetually at work, though never seen?

(Muir 1963, quoted in Holloway, 2012:4).

A process view of spirituality is much more able to encapsulate failure within its remit and therefore encompass risk. There is an ancient saying that you cannot find light unless you are prepared to enter the darkness and that this is part of the process of life. This is taken up by Leonard Cohen in his song Anthem:

Ring the bells that still can ring

Forget your perfect offering

There is a crack, a crack in everything

That's how the light gets in

(Cohen 2012).

Isabel Clarke takes the last two lines of this as title for her chapter on Psychosis and Spirituality in Ways of Knowing (2005). She draws on cognitive psychology (Thalbourne et al., 1997) in setting up a model of the trans-liminal as a 'porous' relation to other beings. This she contrasts with 'propositional knowing'. We cross an internal 'limen' or threshold to reach this way of knowing which is characterised by a both/and logic; this may appear as a way of not-knowing; the ability to live with paradox is the central feature of this not-knowing (Clarke, 2005).

\section{The Arts as spiritual experience}

Alain de Botton and Tina Beattie make an impassioned plea to artists to rethink their teaching in order to enable music to fill the void left by God. Therefore, the task of artists is to enable us to understand the processes of life and our solidarity in accordance with other parts of creation. This is echoed by Jill Dolan writing of music theatre:

Utopia in Performance argues that live performance provides a place where people come together, embodied and passionate, to share experiences of meaning making and imagination that can describe or capture fleeting intimations of a better world (Dolan, 2005:2).

She draws on Joseph Chaikin, founder of the Open Theatre:

[Theatre] becomes a privileged, intimate area of human experience within which one can demand that the promise of another dimension of existence be revealed, and that the impossible be achieved/experienced here and now (quoted in Dolan, 2005:6).

Millie Taylor (2013) develops this idea in her inaugural lecture:

The utopia that Dolan outlines is not a stabilized model nor a self-determined system, not a narrative or realistic representation of a better world, but something always in process, always slightly out of reach, as an approach toward, a momentary experience, and yet as powerfully real as hopes, desires and 'concrete fantasy' (Dolan, 2005:7). These utopian performatives are momentary experiences within performance that 
'exceed the content of a play or performance' (Dolan, 2005:8), and it is in this sense that I am using the term excess today, as something that is beyond what might be anticipated and that lifts us into a moment of illumination that is always ephemeral and evanescent.

She illustrates this from Stephen Sondheim, showing how his song Into the Woods (1987) sets us a contemporary morality based in journeying into difficult places. This thinking is in line with that of Alain de Botton as quoted above; according to Millie Taylor's thinking, the audience finds meaning in and accompaniment on their own journeys through their experience of musical theatre through the previously mentioned song. This is part of the spiritual experience but as we have seen it is, as we have already seen, a complex area and academe has traditionally not gone into it. Jonathan Rowson describes this problem thus:

While there has been a growing normalisation of the idea that person can be 'spiritual but not religious', this designation may actually compound the problem of intellectual embarrassment. It does nothing to clarify what spirituality might mean outside of religious contexts, nor how religion might valuably support and inform non-believers ... The injunction of philosophy is to question assumptions, make distinctions and be logical. If spirituality is to be recognised as something with ontological weight and social standing it also needs an injunction that is culturally recognised, as it was for centuries in the Christian west and still is in many societies worldwide (Rowson, 2013:42-43).

The research at hand has revealed six main areas in which people have an experience of the Divine:

- Through the natural world which I have called Inter-Gaian (concerned with our relationship to the other-than-human world);

- Intrapersonal (within ourselves);

- Interpersonal (our relations with other people);

- Extrapersonal /Ethical (our relations with the wider world, the global context);

- Metaphysical (their experience of God as a voice inside, as an answer to prayer, or as a vision or guiding principle);

- Narrative which "refers to the fund of 'story' in which an individual 'dwells' and that constitutes the primary reference for religious identity" (Pratt, 2012:4) - the stories with which people make sense of our lives.

Jonathan Rowson identifies similar areas when he writes:

Being spiritual can mean safeguarding our sense of sacred, valuing the feeling of belonging or savouring the rapture of intense absorption. And then there is the quintessential gratitude we feel when we periodically notice, as gift and revelation, that we are alive ... It is therefore time to question the common default position that emphasises the autonomous individual striving to consciously construct their own religious belief system as a guide to how they should act in the world. It is not just about sociality. The emerging early $21^{\text {st }}$ century view of human nature indicates we are fundamentally embodied, constituted by evolutionary biology, embedded in complex online and offline networks, largely habitual creatures, highly sensitive to social and cultural norms, riddled with cognitive quirks and biases, and more rationalising than rational (Rowson, 2012:42-43).

These areas do overlap in people's account of their mystical experiences (James, 1903; Pratt 2012). I have already referred to the varying narratives in use in Judaism and Christianity but 
I shall not further deal with the variety of narratives (that characterise other faiths) which people use to explain their metaphysical or religious experiences. These descriptions of the characteristics of these ways into the Divine are drawn from some of the writings about these areas and act rather like a Smorgasbord from which people in various contexts construct what they mean by spirituality:

\section{INTER-GAIAN}

- A sense of oneness and deep relationship with the other-than-human world. (BoyceTillman, 2000 \& 2010; Grey, 2007; Primavesi, 2008).

\section{INTRAPERSONAL}

- An internal sense of empowerment, bliss and realisation. Guy Claxton (2002) links it with being energised and a sense of great clarity like 'a high-spirited child' or 'a spirited horse'.

- A sense of coming home to be at peace and at one with ourselves ... the joy and reconciliation of better knowing ourselves ... and the unity of being at peace with ourselves (Jorgensen, 2008:280).

- An evanescent and fleeting quality that cannot be controlled, which may result in a sense of givenness with a mixture of grace, insight and effort (Tisdell, 2007:533).

- Freedom - a feeling of an opening-up in the experiencer as boundaries start to dissolve and an expansion in the sense of identity.

- The opening up of the intuitive faculties.

- The ability to experiment with new ways of being. Open-mindedness and curiosity replaces fundamentalisms of all kinds, leading to creativity born from unusual associations (Koestler, 1964). This ability is derived largely from the unconscious and symbolic processes (Tisdell, 2007) so that diversity can exist within it easily. This capacity may be manifested in image, symbol, music, and other enculturated expressions. Paradox can be tolerated (Clarke, 2005).

- A sense of transformation and change (Boyce-Tillman, 2002, 2007 \& 2009; Mezirow, 2000).

\section{INTERPERSONAL}

- Empathy - a sense of belonging and being at ease in the world and replacing competition with caring and attempts to bless (Buber, 1970; Laurence, 2010).

\section{EXTRAPERSONAL/ETHICAL}

- A feeling of unity with other beings, people, the cosmos (communitas) (Turner, 1969).

- Peace building within the mind and beyond in a state of inner harmony and clarity, and less often conflicted and self-conscious. Tisdell (2007) describes this as a sense of wholeness, healing, and the interconnectedness of all things resulting in the finding of ultimate meaning. 


\section{METAPHYSICAL}

- A sense of encounter with mystery. This links with the experience of 'contemplative thinking' (Lancaster, 2004).

- A sense of the beyond - the all shall be well of the mystic, Julian of Norwich - a releasing of control - a sense of connection to a life-force, God, higher power or purpose (Tisdell, 2007).

\section{Implications for Music Education}

How does the conveyed argument impact on music education? Education has often reflected the dominant culture - the classical traditions with the emphases that I have just outlined. For example, there are two aesthetics for singing. Music education has been coloured by classical approaches to music making:

Classical perspective emphasizing performance, perfection and virtuosity - the standard or "taproot" aesthetic that has been recognized in music education since its inception in the mid-1800s. The second is an aesthetic for singing which stresses community building, diversity, group collaboration and relationship (Pascale, 2005:167).

The dominance of the classical perspective has meant a devaluing of indigenous singing traditions - the use of singing as I examined at the beginning of this article, to create community:

One of the great losses in life is that, as a nation, most people don't sing now. The idea that a singer was someone exclusive was not there then. Everybody sang. Some sung well, some didn't, but singing was as normal as breathing. We sang up the woods, we sang anywhere. You sang when you felt in the mood-you'd be in the pub and someone would start a song and all of a sudden the whole place lit up (Stradling, 2001).

This has resulted in many being excluded from the musical experience:

One of the biggest barriers to audience engagement is the notion held by many that the arts are simply not for them. The 'it's not for me' syndrome is endemic and conspires to exclude people from experiences that could transform their lives (McMaster, 2008:7).

It is the stress on the excellence of the product demanded by the classical tradition that has underpinned these developments and in order to establish the relationship between spirituality and music I shall draw on John Dewey's idea of the arts as engaged experience. [He] emphasized the importance of:

\section{... direct experience over received knowledge; valued the rough, unpolished quality of vernacular creation over the normative aesthetics of cultural institutions; believed in the pedagogical effectiveness of both experience and art; and saw artistic form as arising out of fully engaged experience (Dewey, 2012: no pages).}

Other theorists like Christopher Small (1998) and Richard Shusterman (2008) have been arguing for a more experience and process-based view of musicking for it is in the process of experiencing music that people enter the realm of contentless experience that is transformational in character and is named by individual cultures or persons in a variety of ways. It includes notions of awe, wonder and mystery (Yob, 2011). 


\section{A Process based model of musicking}

My model of music making emphasises experiencing in all its complexity:

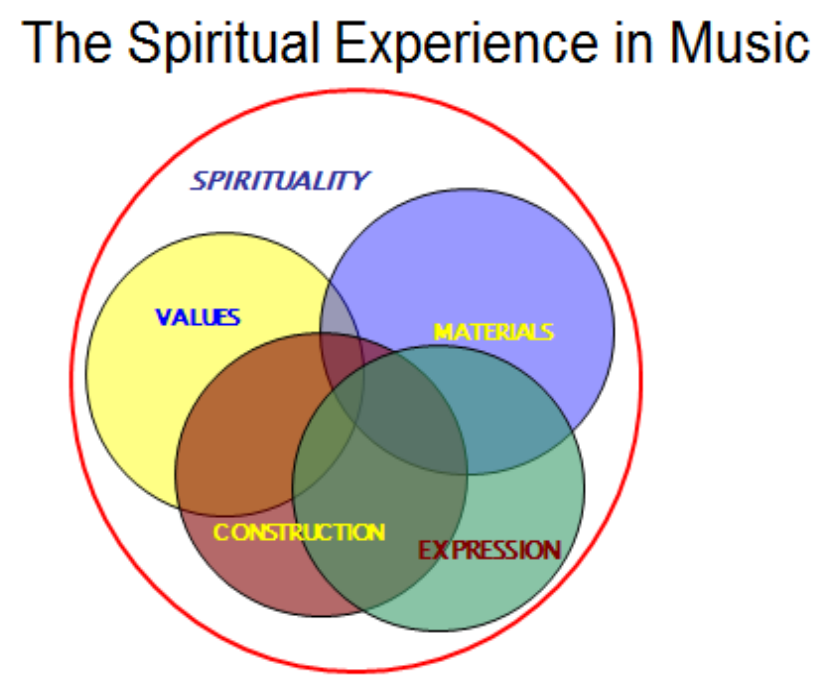

Figure 1: Model for spiritual experience in music Boyce Tillman (2006a)

The model depicted in Figure 1 enables us to understand the complexity of the musical experience with its diverse domains which are experienced with different intensities at different times and in different contexts. This model, with its interlocking domains, easily maps onto the model of spirituality with the inter-Gaian (the relationship with the environment) area sitting in the domain of Materials, the intrapersonal in the domain of Expression, the interpersonal in the domain of Construction, the extra-personal in the domain of Values and the metaphysical in the domain of Spirituality which is encountered by moving through these facets of the crystal.

The research that led to this model was multi-faceted and each facet has its own methodological strategies associated with it. Therefore, the strategies and methodologies used for examining the various circles differ. Traditional musicological techniques for notated music are clearly appropriate in the Construction domain. Techniques drawing on the literature on music therapy help considerably to illuminate the Expression domain while ethnomusicological methodologies illuminate the domain of Values. Organology is a clear part of the domain of Materials as is also the physiology of the body.

The model offers a thick description of the musical experience (Geertz, 1973). It accepts the essential subjectivity of the experience with different aspects gradually becoming apparent as the experiencer views it through different facets of the crystal (Ellingson, 2009). The fluidity of the model enables is to interrogate the process of musicking through different lenses which may present us with various paradoxes.

In the model, the domains interact with one another powerfully. The Expression domain concerns developments within the self (often limited unnecessarily in the past to therapeutic contexts) - the intrapersonal. Rethinking in this domain can also affect interpersonal behaviour in the domain of Construction which is different in literate traditions (performing in orchestras or choirs) from improvised traditions (like jazz and African drumming 
traditions). Such rethinking will cause changes within the domain of Values. Extrapersonal views and behaviours may change and challenge fundamentalisms and understandings of ethical issues in musicking (Boyce-Tillman, 2007c, 2011). In this domain there can be debates about religious narratives in contexts such as education (Boyce-Tillman, 2001). The environmental (Boyce-Tillman, 2010) part of the Material domain is seldom present in educational contexts except in exploring experiences of awe and wonder at the natural world. The Spiritual domain opens up as the domains fuse together in a spontaneous way. The uncoupling of the Spiritual domain (relating the metaphysical experience to contemporary developments in the study of consciousness) from the narratives of the great faiths (located in the model in the domain of Values) offers the possibility of a religionless Spirituality.

There is a developing literature showing how notions of the spiritual can draw on any or all of these domains. Frank Heuser (2012) concentrates on the interpersonal when he claims that music opens up the spiritual essence of the human character which enables individuals to move beyond their own immediate concerns, feel compassion for others, and experience private moments of awe, wonder and transcendence. He suggests that teachers need to "nurture a child's natural capacity for creating meanings and allow Spirituality to unfold in the course of instruction" (Heuser, 2012:116). In the metaphysical area Tina Beattie suggests that:

All theological language, all mysticism and prayer, all art, music and literature, are ways of trying - and failing - to express the 'no-thinglyness' of God (Beattie, 2007:175).

In the domain of Expression sits the area of identity:

Music is a key resource for realizing personal and collective identities ... identities [which] are at once individual and social ... The crucial link between identity formation and arts like music lies in the specific semiotic character of these activities which make them particularly affective and direct ways of knowing (Turino, 1999: 221).

Batzoglou distinguishes this from therapy:

The facilitation of the process aims towards a deeper inner self-exploration rather than therapeutic attendance of the participants' psychopathological needs. This relationship is interpersonal and inter-psychic, happening verbally or non-verbally with the whole group and each individual separately (Batzoglou, 2011:no pages).

In this domain also lie the transformative possibilities of the liminal space both interpersonally and intrapersonally as in the story of a woman brought up in India who was ashamed but could not abandon her anti-Islamic position born of her experience of Islam in her youth. During a Space for Peace event she sat at the foot of the pulpit where the imam was chanting and cried it all away. After it she felt her islamophobia washed away by the crying generated by the music. In a similar event an intrapersonal transformation occurred:

On one side of the West door the Rabbi sang The Lord's Prayer in Hebrew, in a beautiful resonant voice. We had been told we could make a request to the singers, perhaps to sing in memory of someone for example. So I asked the Rabbi to hold someone in his heart when he next sang, my beautiful Mum. It was rich and beautiful. And I wept. I have never asked anyone to do this before, and no one has ever offered. In the past people have said they would remember someone in prayer or thought, but never through music. I didn't know music could be so powerful. That solo voice singing 
with such a depth of intention and love for someone I loved. I shall never ever forget that (Unpublished conversation 2010).

So if we concentrate on the process of experiencing music we can see that it can transform in a variety of ways:

My intention was also to show that music could be a genuine way to create situations, to construct social relations in situations, to communicate in a bolistic way that combines body and ethics, individual and community (Westerlund, 2002:144).

\section{Summary}

I have set out a process model of spirituality drawing from a variety of texts and both contemporary and much older. I have seen how the marginalisation and fluidity within concepts of spirituality and its relationship to well-being, in favour of fixed narratives passed on by means of literary texts have resulted in a fixed, less experiential set of creeds and dogmas; this has resulted in various groups being excluded from religious citadels. I have shown how the rise of the description spiritual but not religious is a challenging of these fixed ideas and how a process based model of musicking reflects the concerns of contemporary writers on spirituality. I have reflected further on the model and seen it in a more crystalline form with various facets or domains through which one can examine the whole.

This enables the encompassing of paradox and mystery within the experience. The Platonic theory of perfect forms coloured the Christian codification of the nature of God and still persists in theories of aesthetics based on an ideal structure situated somewhere in the universe to which our forms of Construction aspire. By adopting a process based model of examining the musicking experience I hope that I have shown you the possibility of aesthetic judgements based on a variety of bases which enable them to be fluid and diverse and varying within various contexts. Spirituality, I have shown, is to be located primarily in the process rather then the product. This is encapsulated in these final words from a US song:

Oh, you gotta get a glory

In the work you do;

A hallelujah chorus

In the heart of you.

Paint, or tell (write) a story,

Sing, or shovel coal,

But you gotta get a glory

Or the job lacks soul (Bradley).

\section{BIBLIOGRAPHY}

Batzoglou, A. 2011. Towards a theatre of psychagogia: an experimental application of the Sesame approach into psychophysical actor training. London: University of London. (Thesis - PhD). 
Beattie, T. 2007. The New Atheists: The Twilight of Reason and the war on religion. London: Darton, Longman and Todd.

Bender, C. 2010. The New Metaphysicals: Spirituality and the American Religious Imagination. Chicago: The University of Chicago Press.

Benedict, C. 2013. Capitalist Rationality - Comparing the Lure of the infinite. Philosophy of Music Education Review, 21(1):8-22.

Boyce-Tillman, J.B. 1991. Towards a Model of Development of Children's Musical Creativity. Canadian Music Educator, 30(2):169-174.

Boyce-Tillman, J.B. 1994. The Role of Women in the passing on of Tradition and its Implications for the School Music Curriculum. (In Musical Connections/Traditions and Change, Proceedings 21st World Conference International Society for Music Education, Tampa, Florida).

Boyce-Tillman, J.B. 1996. A Framework for Intercultural Dialogue (In M. Floyd ed. World Musics in Education. Farnborough: Scholar Books, p. 43-94).

Boyce-Tillman, J.B. 2000a. Constructing Musical Healing: The Wounds that Sing. London: Jessica Kingsley.

Boyce-Tillman, J.B. 2000b. Promoting Well-being through Music Education. Philosophy of Music Education Review, 6(2):89-98.

Boyce-Tillman, J.B. 2000c. The Creative Spirit- Harmonious Living with Hildegard of Bingen. Norwich: Canterbury Press.

Boyce-Tillman, J.B. 2001. Sounding the Sacred: Music as Sacred Site. (In K. RallsMacLeod \& G. Harvey eds. Indigenous Religious Musics. Farnborough: Scolar p. 136-166).

Boyce-Tillman, J.B. 2002a. Subjugated Ways of Knowing. The Journal of Critical Psychology, Counselling and Psychotherapy, 2(4):208-213.

Boyce-Tillman, J.B. 2002b. Sound Balance - Music and Well-being with Young Children. Early Childhood Connections - Journal of Music- and Movement-based learning, 8(2):29-37.

Boyce-Tillman, J.B. 2004. Towards an ecology of music education. Philosophy of Music Education Review, 12(2):102-125.

Boyce-Tillman, J.B. 2005. Ways of Knowing. (In C. Clarke ed. Ways of Knowing: Science and Mysticism today. Exeter, UK: Imprint Academic p. 8-33).

Boyce-Tillman, J.B. 2006a. Music as Spiritual Experience. Modern Believing: Church and Society, 47(3):20-31.

Boyce-Tillman, J.B. 2006b. A Rainbow to Heaven. London: Stainer and Bell.

Boyce-Tillman, J.B. 2007a. The Spirituality of Music Education. (In The International Handbook of Research in Arts Education. Netherlands: Springer p. 1405-1421).

Boyce-Tillman, J.B. 2007b. Unconventional Wisdom. London: Equinox.

Boyce-Tillman, J.B. 2007c. Peace Making in Educational contexts. (In Urbain, O. Music and Conflict transformation: Harmonies and Dissonances in Geopolitics. London: I. B. Tauris p. 212-228). 
Boyce-Tillman, J.B. 2007d. The wounds that sing: Music as Transformation. (In J. Baxter, ed. Wounds that heal: Theology, Imagination and Health. London: SPCK p. 229250).

Boyce-Tillman, J.B. 2009. The Transformative Qualities of a liminal Space created by musicking. Philosophy of Music education review, 17(2) Fall:184-202.

Boyce-Tillman, J.B. 2010. Even the stones cry out: Music Theology and the Earth. (In L. Isherwood \& E. Bellchambers eds. Through us, with us, in us: Relational Theologies in the twenty-first Century. London: SCM Press p. 153-178).

Boyce-Tillman, J.B. 2011. Making Musical Space for Peace. (In Laurence, Felicity and Urbain, Olivier. Peace and Policy Dialogue of Civilization for Global Citizenship, (15) Music and Solidarity: Questions of Universality, Consciousness and Connection. New Brunswick and London: Transaction Publishers p. 185-201).

Boyce-Tillman, J.B. 2012. And still I wander: Deconstructing Music Education through Greek Mythology. Keynote address Musical Paedia, International Society for Music Education Conference, Thessaloniki, July.

Boyce-Tillman, J.B. 2014. The Great Turning. Winchester: Winchester Cathedral. [Musical].

Bradley, B. a.a. You gotta get a glory http://goo.g1/BjumyR Date of access: 14 March 2014.

Buber, M. (translation W. Kaufmann). 1970. I and Thou. New York: Charles Scribner's Sons.

Christ, C. P. 2003. She who changes; Re-imagining the Divine in the world. New York and Basingstoke: Palgrave/Macmillan.

Clarke, I. 2005. There is a crack in everything, that's how the light gets in. (In C. Clarke, ed. Ways of Knowing: Science and Mysticism today, London: Imprint, p. 90-102).

Cohen, L. 2012 Anthem, at http://goo.gl/PVJY9 Date of access: 21 August 2012.

Collins, N. 2013. The Daily Telegraph: 5, 9 July 2013.

Crossan, J. D. 1992. In Parables: The Challenge of the Historical Jesus. Sonoma. California: Polebridge Press.

Daly, M. 1973. Beyond God the Father: Toward a Philosophy of Women's Liberation. Boston: The Beacon Press.

Dawkins, R. 2012. Interview on BBC Radio 4 9am Sept $4^{\text {th }} 2012$.

De Botton, A. 2012. Religion for Atheists; A non-believer's guide to the uses of religion. London: Hamish Hamilton.

Dewey, J. 1934. Art as Experience. New York: Minton Balch.

Dewey, J, 2012. http://goo.g1/1ZFvEr Date of access: 1 June 2012.

Dolan, J. 2005. Utopia in Performance: Finding Hope at the Theater. Michigan: University of Michigan.

Dupre, L. 1990. World Spirituality: An Encyclopaedic History of Religious Quest. New York: Crossroad. 
Ellingson, L. 2009. Engaging Crystallization in Qualitative Research: An Introduction. London: Sage.

Ellis, C.J. 1985. Aboriginal Music - Education for living. Queensland: University of Queensland Press.

Foucault, M. \& Gordon, C. eds. 1980. Power Knowledge: Selected Interviews and Other writings 1972-77. Hemel Hempstead: Harvester Wheatsheaf.

Foskett, J. 1984. Meaning in Madness - The Pastor and the mentally ill. London: SPCK.

Fuller, R. 2001. Spiritual but not religious: Understanding Unchurched America. Oxford: Oxford University Press.

Geertz, C. 1973. The Interpretation of Cultures: Selected Essays. New York: Basic.

Grey, M. 1989. Weaving New Connections: The Promise of process Thought for Christian Theology. Holland: University of Nijmegen. (Inaugural lecture).

Grey, M. 2007. Ecomysticism: a contemporary path of Christian healing. (In J. Baxter ed. Wounds that heal: Theology, Imagination and Health. London: SPCK p 36-56).

Heelas, P. \& Woodhead, L. 2005. The Spiritual Revolution: why religion is giving way to spirituality. Oxford: Blackwell.

Helman, C.G. 1994. Culture, health and Illness. London: Butterworth/Heinemann.

Heuser, F. 2012. Secular Spirituality in the Music Classroom. Paper presented at Musical Paedia, International Society for Music Education Conference, Thessaloniki, p. 116117.

Holloway, R. 2013. Leaving Alexandria - A memoir of faith and doubt. Edinburgh: Canongate.

Huxley, A. 1945. The Perennial Philosophy. New York: Harper \& Brothers.

Illich, I. 1972. Deschooling Society. New York: Harper and Row.

James, W. 1903. 1997 ed. The Varieties of Religious Experience. New York: Simon and Schuster.

Jorgensen, E.J. 2008. The Art of Teaching Music. Bloomington and Indianapolis: Indiana University Press.

Keller, K. \& Daniell, A. 2002. Process and Difference: Between Cosmological and Poststructuralist Postmodernisms. New York: Suny.

King, U. 2009. The Search for Spirituality - Our global quest for meaning and fulfilment. Norwich: Canterbury Press.

Koestler, A. 1964. The Act of Creation. London, Hutchinson.

Lancaster, B.L. 2004. Approaches to Consciousness: The Marriage of Science and Mysticism. London: Palgrave Macmillan.

Laurence, F. 2010. Introduction. Peace \& Policy Dialogue of Civilizations for Global Citizenship, 15:9-19.

Lyon, J. 1999. Manifestos: Provocations of the modern. New York: Cornell University.

Mantin, R. 2002. Theologies in Process: the role of Goddess-talk in feminist spirituality. Southampton: Southampton University. (Thesis - PhD). 
Marton, F. \& Booth, S. 1997. Learning and Awareness. Mahwah New Jersey: Lawrence Erlbaum Associates.

MacFarlane, A. 2005. Letters to Lily on how the World Works. London: Profile Books.

McMaster, B. 2008. McMaster Review Supporting Excellence in the Arts - From Measurement to Judgment Department of Culture, Media and Sport http://goo.gl/1jY1Mq Date of access: 15 March 2014.

Mezirow, J. \& associates. 2000. Learning as Transformation: Critical Perspectives on a Theory in Process. San Francisco: Jossey-Bass.

Nussbaum, M. C. 2012. The New Religious Intolerance: Overcoming the politics of fear in an anxious age. London: Belknap Press of Harvard University Press.

Bertell, O. 1976. Alienation: Marx's Conception of Man in Capitalist society. Cambridge: Cambridge University Press.

Ong, W. 1982. Orality and Literacy: The Technologizing of the Word. New York: Methuen.

Pascale, L. 2005. Dispelling the Myth of The Non-Singer - Embracing Two Aesthetics for Singing. Philosophy of Music Education Review, 13(2):165-175.

Pratt, D. 2012. The Persistence and problem of Religion: exclusivist Boundaries and Extremist Transgressions. Paper presented at the Conference of the British Association for the Study of Religion, 6 Sept. Winchester: University of Winchester.

Pullman, P. 2000. The Amber Spyglass. Oxford: David Fickling Books.

Richardson, L. 2000. Writing: A method of enquiry. (In N.K. Denzin \& Y.S. Lincoln eds. Handbook of qualitative research. Thousand Oaks CA: Sage. p. 923-943).

Rowson, J. 2013. The Brains behind Spirituality. RSA Journal Summer, 40-43.

Shusterman, R. 2008. Body Consciousness: A Philosophy of Mindfulness and Somaesthetics. Cambridge: Cambridge University Press.

Small, C. 1998. Musicking: The Meanings of Performing and Listening. Hanover: Wesleyan University Press.

Storr, A. 1993. Music and the Mind. London: HarperCollins.

Stradling, R. 2001. Just Another Saturday night. Musical Traditions. www.mustrad.org.uk/articles/saturday. Date of access: 15 March 2014.

Taylor, M. 2013. Humanity, Community and Excess: "Feel the flow". (In Musical theatre performance. Inaugural lectures Professor of Music Theatre). Winchester: University of Winchester.

Thalbourne, M.A., Bartemucci, L., Delin, P.S., Fox, B. \& Nofi, O. 1997. Transliminality, Its nature and correlates. The Journal of the American Society for Psychical Research, 91:305-310.

Tillman, J.B. 1987. Towards a model of the development of musical creativity: A Study of the Compositions of Children aged 3-11. London: University of London Institute of Education. (Thesis - PhD).

Tisdell, E. J. 2007. In the new millennium: The role of spirituality and the cultural imagination in dealing with diversity and equity in the higher education classroom. Teachers College Record, 109:531-560. 
Turino, T. 1999. Signs of Imagination, Identity, and Experience: A Peircian Semiotic Theory for Music. Ethnomusicology, 43(2): 221-255.

Turner, V. 1969. The Ritual process: Structure and Anti-structure. Baltimore: Penguin Books.

Tutu, D. 2008. Ubuntu Women Institute USA (UWIU) with SSIWEL as its first South Sudan Project. http://www.ssiwel.org. Date of access 20 April 2011.

Westerlund, H. 2002. Bridging Experience, Action, and Culture in Music Education. Studia Musica 16, Helsinki: Sibelius Academy.

Whitehead, A.N. 1929. Process and Reality. An Essay in Cosmology. Gifford Lectures Delivered in the University of Edinburgh During the Session 1927-1928. New York: Macmillan.

Wigglesworth, C. 2012. SQ21: The twenty-one skills of spiritual Intelligence. New York: Select Books.

Wilber, K. 2009. The Eye of the Spirit- An integral Vision for a world gone slightly mad. Shambhala Publications. twm.co.nz/kwilb_eyspir.html. Date of access: 14 April 2009.

Yob, I. 2011. If we knew what spirituality was we would teach for it. Music educators Journal, 98(2), 41-47. 